\title{
Population Fluctuation and Faunistic Analysis of Fruit Flies in a Commercial Guava Orchard (Psidium guajava L.)
}

\author{
Júlio César G. Alves ${ }^{1}$, Carlos Henrique de Brito ${ }^{1}$, Robério de Oliveira ${ }^{1}$, Clarice D. A. Corsato ${ }^{2}$, \\ Vinícius de O. Barbosa ${ }^{3}$, Jakellyne F. da Silva ${ }^{1}$, Jacinto de L. Batista ${ }^{1}$ \\ \& Gleidyane N. Lopes ${ }^{1}$ \\ ${ }^{1}$ Centro de Ciências Agrárias, Universidade Federal da Paraíba, Areia, PB, Brazil \\ ${ }^{2}$ Universidade Estadual de Montes Claros, Janaúba, Minas Gerais, Brazil \\ ${ }^{3}$ Universidade Federal da Grande Dourados, Dourados, Mato Grosso do Sul, Brazil
}

Correspondence: Robério de Oliveira, Centro de Ciências Agrárias, Vila Acadêmica/Cidade Universitária-Campus II, CEP: 58.397-000, Rodovia BR 079-Km 12, Areia, Paraíba, Brazil. Tel: 55-839-9673-9265. E-mail: roberio_b19@yahoo.com.br

Received: March 14, 2019

doi:10.5539/jas.v11n9p145

\author{
Accepted: April 27, $2019 \quad$ Online Published: June 30, 2019 \\ URL: https://doi.org/10.5539/jas.v11n9p145
}

\begin{abstract}
Knowledge of the population fluctuation of a pest in an orchard allows the producer preventing and making use of techniques that control the insect pest before it causes economic damages. The objective of the present work was to verify fruit fly species population dynamics in a commercial of Psidium guajava L. (Myrtaceae) orchard in the Curimataú microregion of Paraíba, also to characterize the community of fruit flies through faunistic analysis as well. Fruits were collected biweekly, the total was 24 collections between August 2014 and July 2015 in the municipality of Nova Floresta-PB. Fruits were preferentially collected mature or at the beginning of maturation, differentiating fruits harvested on the soil, plants, and through PET traps containing different food attractants. After collection, fruits were kept in plastic trays filled with a layer of two centimeters of sterilized sand and covered with fabric 'voil'. The trays were labeled with the field data and placed in a greenhouse. Past the period of 15-25 days the fruits, already in the stage of decomposition were examined in order to collect pupae and larvae of $3^{\text {rd }}$ instar. A total of 462 specimens of fruit flies were collected in 12 months sampling period, they were collected from fruits gathered from the ground and from the tree, and through trapping, being 209 males and 253 females, all collected in P. guajava. From the results obtained during the sampling period, a total of four species were recorded by fruit collection and six species by a trap. A new specimen of Anastrepha was found that there was no register in Paraíba yet, Anastrepha hadropickeli Canal, Uramoto and Zucchi (2013), as well as a Rhagoletis sp. (Loew).
\end{abstract}

Keywords: Anastrepha spp., Ceratitis capitata, prague quarantine

\section{Introduction}

Knowledge of fruit flies population dynamics and faunal analyses have fundamental importance for all producers who grow fruit in the world, because through analysis of these parameters producers can get answers from within the orchard, as an example, which pest is specifically considered as key plague, knowing seasonal period that occurs a particular species of fruit fly, availability of food and even know the influence of environmental factors such as rainfall, temperature, and relative air humidity exert in the orchard. And having these answers, producer adopts management practices that allow reducing usage of agrochemicals and also favoring regional and local biodiversity.

Previous knowledge of fruit flies species and their hosts in an area of fruit cultivation is fundamental to establish a control program fruit fly (Uramoto, 2002). Introduced hosts are the most infested by Ceratitis capitata Wiedemann (1824), while natives are the most infested by Anastrepha (Malavasi \& Morgante, 1980). Host availability is a factor that influences infestation levels, having a proportional increase in population and infestation (Malavasi \& Morgante, 1980). The existence of a great diversity of hosts with fruits maturing in different seasons of the year keeps high the density of these Tephritidae (Raga et al., 1996). 
The use of food substances associated with traps for fruit flies monitoring has great utility to determine the ideal moment for applications of toxic baits, achieving a reduction on expenses and harmful effect of toxic baits to the beneficial fauna as predators and parasitoids (Rampazzo, 1994).

Fruit fly infestation is considered the main obstacle in the commercialization and exportation of the production, characterizing itself as the biggest fruit trees pest of the country, whose damages are due to both the adult females oviposition as the feeding of the larvae that accelerate maturation and lead to the early fall of fruit (Fofonka, 2006).

Fruit analysis or sampling allows to evaluate the level of fruit infestation and to precisely identify an association of certain Tephritidae with the vegetable species or fruit variety (Malavasi et al., 2000). Traps with food baits allow a general collection Tephritidae (Uramoto et al., 2005). Therefore, monitoring should be complemented with fruit sampling to assess the level of infestation and to accurately identify the association of a particular species of fruit flies with a cultivated variety (Alves, 2010).

For this purpose, a sample of 0.5 to $5.0 \mathrm{~kg}$ per hectare of ripe fruit from the tree or from the ground should be collected when still intact, and then placed in containers with vermiculite, sawdust or sand (Malavasi, 2000). From seven to fifteen days vermiculite must be sieved to obtain puparia, which should be transferred to a new container having vermiculite, where adults will emerge. After they have emerged, they will be placed in alcohol $70.0 \%$ for later identification and then to calculate emergence rates, pupal viability, richness, frequency, dominance among other indices that help to monitor this pest.

Thus, this work was carried out with the objective of studying the fruit fly species population fluctuation in a commercial guava orchard in the Curimataú microregion of Paraíba, as well to characterize the fruit flies community through faunistic analysis.

\section{Material and Methods}

\subsection{Experimental Area}

The study was conducted in the Fazenda Monte Videl, in the Nova Floresta municipality, State of Paraíba with geographical coordinates S: $06^{\circ} 27^{\prime} 38.79^{\prime \prime}$ and W: $36^{\circ} 12^{\prime} 36.99^{\prime \prime}$, total area of 12 hectares, where is located the orchard to do guava exploration P. guajava L. (Myrtaceae) with a total area of 2.5 hectares. Region climate is classified as As', hot and dry, with concentrated rains in the months of March to July (Köppen \& Geiger, 1936). The orchard mentioned above has a spacing of $6.0 \times 4.0$ meters with a height of plants around 2.5 to 3.0 meters and age approximately \pm 8 years, where predominantly cultivated variety is Paluma. The property also has a diversity of fruit species such as orange, graviola, lemon, acerola, cashew, and mango.The population survey of fruit flies in guava plants was carried out from August 2014 to July 2015.

\subsection{Fruit Picking and Adults Collection Insects}

Fruits were collected biweekly in the guava orchard, where they were selected, preferably, ripe fruits or at the beginning of maturation, then fruits gathered from the ground were separated from fruits gathered from the tree.

After harvesting, fruits were transported in plastic bags to the Laboratory of Invertebrate Zoology, Department of Biological Sciences/Agricultural Sciences Center of the Federal University of Paraíba-Areia, PB, where they were counted, weighed and kept in plastic trays filled with a layer of two centimeters of sterilized sand and covered with 'voil'. The trays were labeled with field data and placed in a greenhouse. After a period of 15-25 days, the fruits were examined in order to collect $3^{\text {rd }}$ instar larvae and later discarded. The trays were examined daily and the collected pupae were placed in Petri dishes with sterilized sand, covered by 'voil' fabric and kept in the laboratory until the emergence of adults and/or parasitoids.

\subsection{Adults Collection Through Traps}

Adult fruit flies monitoring were carried out with the aid of plastics traps type PET bottle containing different food attractants: corn hydrolyzed protein (Bio Anastrepha ${ }^{\circledR}$ ) $5.0 \%(400 \mathrm{~mL}$ water $+30 \mathrm{~mL}$ protein); sugarcane molasses $(400 \mathrm{~mL}$ water $+40 \mathrm{~mL}$ molasses) at $10.0 \%$; and guava fruit juice $(400 \mathrm{~mL}$ water $+40 \mathrm{~g}$ sugar +120 $\mathrm{mL}$ juice) at $30.0 \%$. The experimental design was a randomized block with three treatments and 10 replications, each block consisted of a plant containing each of three PET traps having food attractants, a total of 30 PET bottles. Traps were installed on the central part of the trees approximately $1.50 \mathrm{~m}$ above the ground. Flasks were inspected biweekly, the occasion that captured fly specimens were collected and food attractants replaced. These specimens were washed with water on a sieve and well packed in plastic containers with hydrated alcohol $70.0 \%$ being properly labeled and then forwarded to the laboratory already mentioned in order to perform the screening 
of the material, where males and females of Ceratitis and Anastrepha genera were separated and preserved in alcohol at $70.0 \%$ for species future identification.

\subsection{Identification of Fruit Flies Species}

Samples of fruit flies were separated by sex and just females were identified through aculeus present in the ovipositor, since males did not present diagnostic characters for the specific identification (Uramoto, 2002), using identification keys (Zucchi, 2003).

In order to proceed with the identification, aculeus of females have been turned inside out, detached from the eversible membrane and assembled in glycerin between slide and coverslip and examined under a magnifying glass and optical microscope.

\subsection{Population Dynamics of the Fruit Flies}

Population fluctuation was based on the total number of adult females of Anastrepha and Ceratitis per month, being analyzed in relation to the rainfall and temperature in each food attractant by the calculation of MAD index. Climatic data were obtained from the PROCLIMA website.

\subsection{MAD Index}

The MAD index was calculated using the formula: $\mathrm{MAD}=\mathrm{N} / \mathrm{A} \times \mathrm{D}$, where MAD $=$ flies/trap/day; $\mathrm{N}=$ total number of flies caught; $\mathrm{A}=$ number of traps evaluated and $\mathrm{D}=$ interval in days between collections (Silveira Neto et al., 1976).

\subsection{Faunistic Analysis}

Based on fruits gathered and individuals collected in the traps (faunistic analysis) the following parameters were evaluated: frequency, constancy (C), wealth (S), number of dominant species, Simpson index, Shannon index, modified Hill index (E). Faunistic analysis of fruit flies species (Silveira Neto et al., 1976; Uramoto, 2002).

\section{Results and Discussion}

\subsection{Population Fluctuation of Fruit Flies}

As for the specific population fluctuation of adult fruit flies related to the average monthly precipitation, in which the species Anastrepha sororcula Zucchi (1979) occurred more frequently during the sampling period with a population peak in the months of June and July 2015, when precipitation was around 60 to $80 \mathrm{~mm}$ (Figure 1). This fact may probably be explained as a function of rainfall has occurred more intensely between mid-February/2015 and mid-April/2015, with a precipitation peak in the month of March/2015. Linked to this fact, there is also a presence of host plants for this species such as acerola Malpighia glabra L. (Malpighiaceae) surrounding the orchard, in addition to a strip of native forest near the orchard of guava trees that could be favoring the presence of this species.

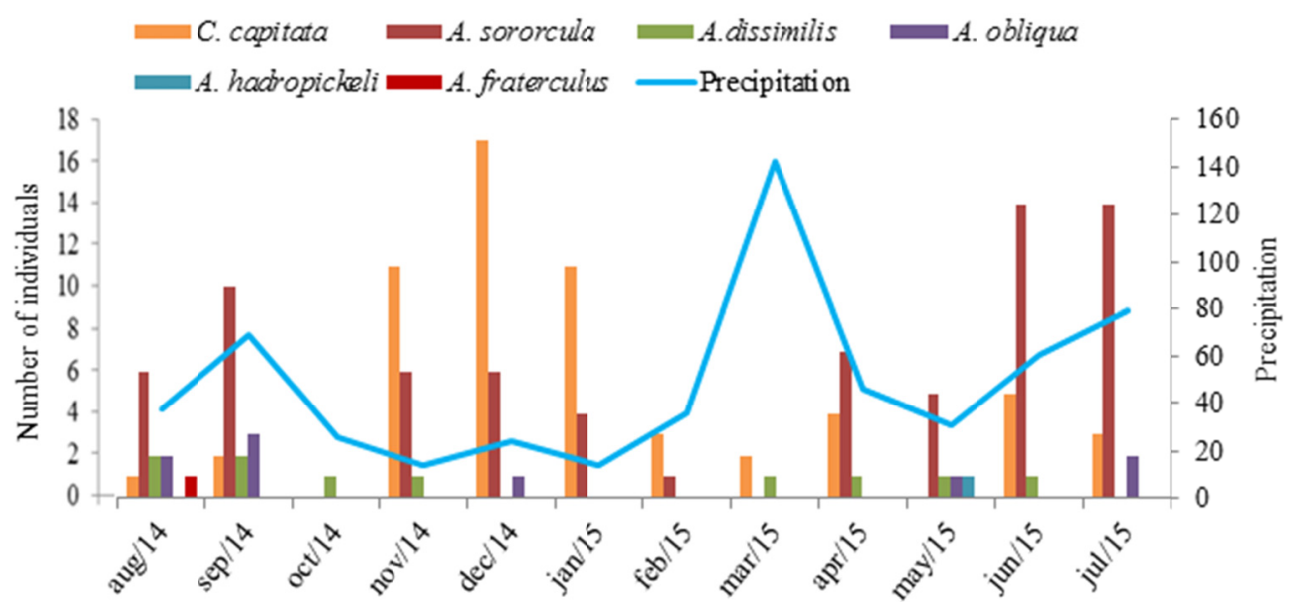

Figure 1. Relation of the specific population fluctuation of fruit flies with the precipitation, captured in traps type PET in a commercial guava orchard in the municipality of Nova Floresta-PB from August/2014 to July/2015

It is verified also in the (Figure 1), that the Ceratitis capitata species presented a considerable frequency during the sampling period, especially from the month of November/2014 to January/2015 with a population peak in 
December/2014. In orchards of a single fruit tree, its population reaches its population peak soon after the fruit ripening and falls when there is no host available (Aluja, 1994; Nascimento et al., 2000). In the present research, the presence of alternative host plants, as previously reported, allied to the availability of guava fruits, explains the highest population peak of $C$. capitata in the referred months, similar to what occurred with A. sororcula. The frugivorous flies (Tephritidae and Lonchaeidae) in the Mossoró region of Rio Grande do Norte, registered that the most important factors that influenced the infestation levels in guava fruits were adult population, availability of host, temperature, and rainfall (Araújo, 2002). Adult fruit flies survival throughout the year may be feasible even within the same property, if there are different cultivars and citrus species because some have several cycles of fruiting (Raga, 2005).

\subsection{MAD Index}

MAD index within a fruit orchard is more than important, it is essential because through this index decisions can be made before pests cause economic damages to the producer, besides also being an index that establishes standards of internal and external trade. It was observed that the highest MAD, compared to the precipitation, was during the month of September/2014, reaching 0.046 coinciding with the runoff period of the orchard production (Figure 2). When the fruits destination is the United States, the MAD index must be less than 1, while for Brazil, this index must be equal to 0.5 or greater than 0.5 , therefore in the guava orchard where this experiment was developed the highest rate found is far from reaching the reference MAD for the country (Paranhos, 2005). This index relatively low might be related to the fruit flies population variations, that although do not occur in a standardized and defined manner, might be linked to climatic factors and the availability or suitability of hosts (Salles, 1995; Canesin \& Uchoa-Fernandes, 2007; Alberti et al., 2012).

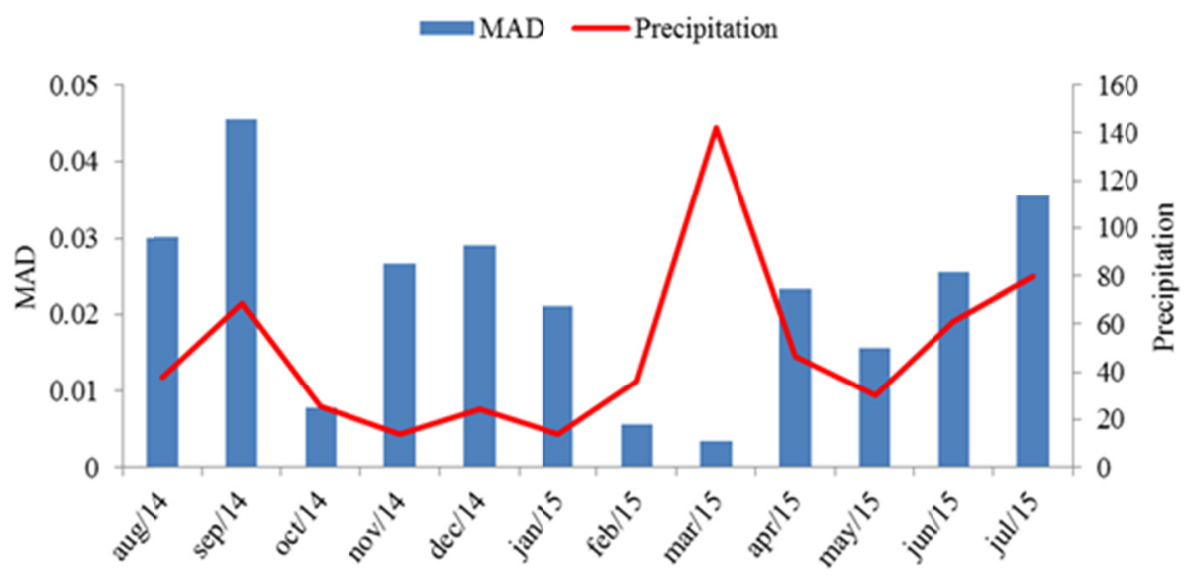

Figure 2. Relation of MAD index (flies/trap/day) and rainfall of the fruit flies (male and female) captured in PET type traps in a commercial guava orchard in the municipality of Nova Floresta-PB from August 2014 to July 2015

Through monitoring using attractant traps can be known the period of greatest infestation in the orchard, as well as the period of beginning control. For this study, the MAD index that suggests the beginning of the control was not reached, thus there is a tendency to this index to increase in the month of September, therefore it is recommended to initiate the control measures with chemical products before population peak period.

The relation between infestation and MAD index varied a little about amounts of puparia/kg (Figure 3), then presented higher rates between the months of April 2015 and June 2015, with the highest number of puparia/kg in the month of May 2015 (0.35 puparia/ $/ \mathrm{kg})$. The average rate of Anastrepha infestation in guava of 58.7 puparia $/ \mathrm{kg}$, in the municipality of Santo Antônio da Alegria (SP), is A. sororcula the most common species (Bressan \& Teles, 1991). In the Cerrado area of Goiás, it was checked the mean index of infestation of 37.9 puparia/kg, being A. sororcula and Anastrepha fraterculus Wiedemann (1830) the predominant species (Veloso, 1997). In Mossoró/Assu, RN, place where Anastrepha species infested with greater intensity Ziziphus joazeiro Mart. (Rhamnaceae), Spondias sp. (Anacardiaceae) and P. guajava, with average infestation rates of 67, 32.3 and 32.1 puparia/kg of fruit respectively (Araújo, 2002). The author reports occurrence of major infestations of $C$. capitata in Fortunella sp. (Rutaceae), Averrhoa carambola L. (Oxalidaceae) and Spondias purpurea L. (Anacardiaceae) with 159, 118 and 34 puparia/kg respectively. 


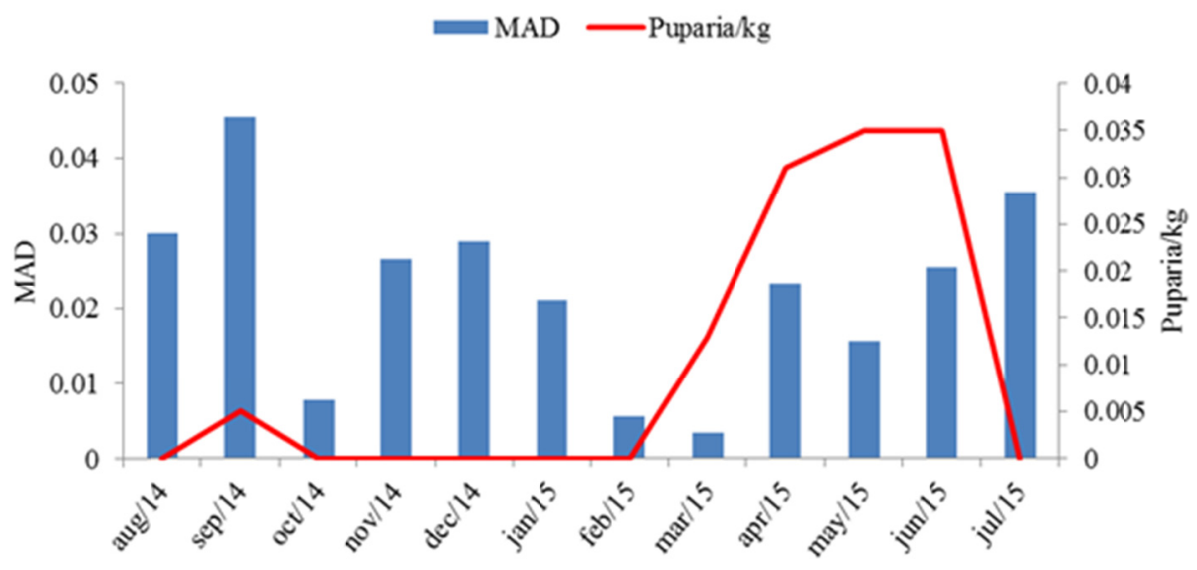

Figure 3. Relation between infestation levels and MAD index (flies/trap/day) of fruit flies (males and females) captured in PET traps in a commercial guava orchard in the municipality of Nova Floresta-PB in the period

August 2014-July 2015

In general, the low MAD indexes of this work can be explained by fruitless in the orchard, as a result of a pruning performed by the producer during the sampling period, and also for the fact that a constant cleaning was performed in the orchard because fruits fallen in the soil were distributed to the birds (chicken) as a food source. These practices were already part of the routine of granja administrator as an attempt to mitigate the incidence of fruit flies in the orchard, thus this way would break the biological cycle of the pest and prevent the emergence of new flies. The systematic accomplishment of cultural treatments in areas cultivated with fruit trees, eliminating fruits fallen to the ground, implies in the eradication of oviposition sites for the fruit flies, thus reducing their population (Uramoto, 2002).

\subsection{Faunistic Analysis of Fruit Flies}

The dominance of Anastrepha sororcula species for the fruits collected on the soil and on the plant presented a frequency of $87.76 \%$, and constancy of 57.14. This was probably due to the fact that flies of this species have a preference for plants of the Myrtaceae family, becoming the most abundant species in the orchard. For Malavasi et al., (2000) depending on the region the key pest status may vary, since, in the semi-arid regions, A. fraterculus loses loose the status of the main pest to Anastrepha zenildae Zucchi (1979) and A. sororcula (Canal et al., 1998). The species Anastrepha obliqua Macquart (1835) and A. zenildae were non-dominant and accidental. However, C. capitata was non-dominant but remained constant during the sampling period (Table 1). Such results corroborate with this research, since it was found that in several Brazilian states only one or two species are predominant particularly in homogeneous commercial orchards where the key pests are usually found, although a big diversity of fruit fly can be found because of adjacent agroecosystems or surrounding native vegetation of the environment (Malavasi \& Morgante, 1980; Uramoto et al., 2005; Fofonka, 2006).

Table 1. Dominance, frequency, and constancy of fruit fly species (females) obtained from fruits (collected on the ground and plant) in a commercial guava orchard in the municipality of Nova Floresta from August/2014 to July/2015

\begin{tabular}{lllllll}
\hline Species & $\mathrm{N}$ & Dominance* & Samples** & \multicolumn{2}{c}{ Frequency (\%) } & \multicolumn{2}{c}{ Constancy } \\
\hline A. sororcula & 86 & $\mathrm{D}$ & 04 & 87.76 & 57.14 & $\mathrm{w}$ \\
A. obliqua & 01 & $\mathrm{~N}$ & 01 & 1.02 & 14.29 & $\mathrm{z}$ \\
A. zenildae & 02 & $\mathrm{~N}$ & 01 & 2.04 & 14.29 & $\mathrm{z}$ \\
C. capitata & 09 & $\mathrm{~N}$ & 04 & 9.18 & 57.14 & $\mathrm{w}$ \\
\hline
\end{tabular}

Note. $\mathrm{N}=$ Collected females total number; $\mathrm{w}=$ constant; $\mathrm{y}=$ accessory; $\mathrm{z}=$ accidental; $* \mathrm{D}=$ dominant, $\mathrm{N}=$ non-dominant** number of samples with the species.

Among Anastrepha female species, only Anastrepha sororcula was considered as dominant for fruit fly caught with the aid of PET traps, it was present in 17 samples, with a frequency of $47.71 \%$, confirming the data 
obtained from the fruits collected from the soil and plant. Other species of Anastrepha (Anastrepha dissimilis Stone (1942); A. obliqua; Anastrepha hadropickeli Canal, Uramoto and Zucchi (2013) and A. fraterculus) were considered non-dominant, being A. dissimilis and A. obliqua as accessories and A. hadropickeli and A. fraterculus as accidental (Table 2). Differently from the data obtained from fruits collected from the soil and plant C. capitata was considered as dominant, frequency of $38.56 \%$ and constancy of 70.83 (Constant). Faunistic indexes such as abundance, dominance, frequency, constancy and wealth are used to characterize the community of Tephritids. These rates show that, despite the existence of several species in a given area, only one or two species are considered dominant and that occurrence is directly related to other factors, among them the presence of host plants (Silva, 2007).

The highest dominance of just one or two species was also found in other regions of Brazil by several authors in similar studies (Nascimento et al., 1983; Kovaleski, 1997; Veloso, 1997; Canal et al., 1998; Garcia \& Corseuil, 1998; Uramoto, 2002; Garcia et al., 2003; Urumato et al., 2004).

Table 2. Dominance, frequency and constancy of fruit fly species (females) captured in PET traps in a commercial guava orchard in the municipality of Nova Floresta-PB in the period of August 2014 to July 2015

\begin{tabular}{lllllll}
\hline Species & $\mathrm{N}$ & Dominance* & Samples** & Frequency (\%) & \multicolumn{2}{c}{ Constancy } \\
\hline A. sororcula & 73 & $\mathrm{D}$ & 17 & 47.71 & 70.83 & $\mathrm{w}$ \\
A. dissimilis & 10 & $\mathrm{~N}$ & 09 & 6.54 & 41.67 & $\mathrm{y}$ \\
A. obliqua & 09 & $\mathrm{~N}$ & 07 & 5.89 & 37.50 & $\mathrm{y}$ \\
A. hadropikceli & 01 & $\mathrm{~N}$ & 01 & 0.65 & 4.17 & $\mathrm{Z}$ \\
A. fraterculus & 01 & $\mathrm{~N}$ & 01 & 0.65 & 4.17 & $\mathrm{z}$ \\
C. capitata & 59 & $\mathrm{D}$ & 17 & 38.56 & 70.83 & $\mathrm{w}$ \\
\hline
\end{tabular}

Note. $\mathrm{N}=$ Collected females total number; $\mathrm{w}=$ constant; $\mathrm{y}=$ accessory; $\mathrm{z}=$ accidental; $* \mathrm{D}=$ dominant, $\mathrm{N}=$ non-dominant $* *$ number of samples with the species.

Analyzed specific faunistic indexes for fruit fly species (females) captured in PET type traps per guava tree (Table 3). It was noted that the plant that captured the largest quantity of females for both genera Anastrepha and Ceratitis was the plant 7 , with a frequency of $19.61 \%$ and a specific richness equal to 3 . It was observed also Plants 4, 8 and 9 were the ones that presented the highest specific richness $\mathrm{S}=4$, in the plants 4 and 8 were caught the same examples of flies (A. sororcula, A. dissimilis, C. capitata and A. obliqua) and in the plant 9 were captured A. sororcula, A. dissimilis, A. fraterculus and C. capitata species.

Plant 7 specifically, it was found that it was located in an area near the border near to plants of citrus and graviola, which possibly provided more constant and easier access of fruit flies with this plant. In general, traps that are located near forest areas capture more species diversity than those located within orchards (Kovaleski et al., 2000). In forest areas, there were wild hosts and it is believed that these migratory movements are due to the search for oviposition sites, scarce in the forest areas in some periods (Sugayama \& Malavasi, 2000). Female of C. capitata, having mature ovaries tend to remain in their host plants, while there is fruit available for oviposition and as soon as they become scarce, there is a rapid dispersion (Yuval \& Hendrichs, 2001).

From the traps placed on plant 9, it was observed low values for frequency, but their Simpson diversity, Shannon and Hill diversity indexes were the highest among the 10 plants selected in the orchard, being $0.7500,1.3860$ and 1.0000 respectively. Thus, even this plant presenting a richness $S=4$, its diversity indexes were higher due to the low fruit fly catch in the orchard during the sampling period, since these values have proportionality character, a low number of captured specimens conferred higher rates of Simpson, Shannon, and Hill modified.

In commercial mango orchards from five different locations in southern Mexico (Aluja et al., 1996) also obtained low diversity indexes, ranging from 0.3 to 1.3, which A. obliqua and Anastrepha ludens Loew (1873) were responsible for $96.6 \%, 66.2 \%$, and $30.4 \%$, respectively, of the total females caught in McPhail traps. They concluded that several species of Anastrepha can be found in an orchard, but one or two of these species usually represent more than $90.0 \%$ of all the flies caught in the traps. Low diversity indexes varying from 0.9 to 2.0 , which A. fraterculus is predominant in the four studied municipalities in the western region of Santa Catarina (Garcia et al., 2003). 
Table 3. Specific Faunistic indexes analyzed for fruit fly species (females) captured in PET traps in a commercial guava orchard in the municipality of Nova Floresta-PB from August/2014 to July/2015

\begin{tabular}{|c|c|c|c|c|c|c|c|c|c|c|c|}
\hline Plant & A. sororcula & A. dissimilis & A. obliqua & A. fraterculus & A. hadropickeli & C. capitata & pi & $\mathbf{S}$ & $\lambda$ & $\mathbf{H}^{\prime}$ & $\mathbf{E}$ \\
\hline 1 & 04 & - & - & - & - & 07 & 7.19 & 2 & 0.4628 & 0.6555 & 0.9457 \\
\hline 2 & 04 & - & 01 & - & - & 18 & 15.03 & 3 & 0.3554 & 0.6324 & 0.5756 \\
\hline 3 & 09 & - & 02 & - & - & 03 & 9.15 & 3 & 0.5204 & 0.8921 & 0.8120 \\
\hline 4 & 14 & 01 & 04 & - & - & 04 & 15.03 & 4 & 0.5671 & 1.0470 & 0.7552 \\
\hline 5 & 03 & 02 & - & - & - & - & 3.27 & 2 & 0.4800 & 0.6730 & 0.9710 \\
\hline 6 & 02 & - & 01 & - & 01 & - & 2.61 & 3 & 0.6250 & 1.04 & 0.9464 \\
\hline 7 & 16 & 02 & - & - & - & 12 & 19.61 & 3 & 0.0511 & 0.8823 & 0.8031 \\
\hline 8 & 08 & 04 & 01 & - & - & 02 & 9.80 & 4 & 0.6222 & 1.1370 & 0.8201 \\
\hline 9 & 01 & 01 & - & 01 & - & 03 & 3.92 & 4 & 0.7500 & 1.3860 & 1.0000 \\
\hline 10 & 12 & - & - & - & - & 10 & 14.38 & 2 & 0.4959 & 0.6890 & 0.9940 \\
\hline
\end{tabular}

\section{Conclusions}

A total of seven species of fruit flies were captured in fruits and traps in the commercial guava orchard in Curimataú of Paraíba, these six species belonging to the genus Anastrepha (A. fraterculus, A. obliqua, A. dissimilis, A. hadropickeli, A. sororcula and A. zenildae) and the C. capitata species;

A new species was found in the state of Paraíba, Anastrepha hadropickeli, Anastrepha sororcula and Ceratitis capitata are the most dominant, frequent and constant species caught in traps installed in the commercial $P$. guajava orchard in the municipality of Nova Floresta-PB;

Calculations for flies/trap/day (MAD) do not reach expressive levels for the producer to enter with a chemical control measure.

\section{Acknowledgements}

The authors thank to Coordenação de Aperfeiçoamento de Pessoal de Nível Superior (CAPES), for granting scholarships.

\section{References}

Alberti, S., Bogus, G. M., \& Garcia, F. R. M. (2012). Flutuação populacional de moscas-das-frutas (Diptera, Tephritidae) em pomares de pessegueiro e maracujazeiro em Iraceminha, Santa Catarina. Biotemas, 25(1), 53-58. https://doi.org/10.5007/2175-7925.2012v25n2p53

Aluja, M. (1994). Bionomics and management of Anastrepha. Annual Review of Entomology, 39(1), $155-178$. https://doi.org/10.1146/annurev.en.39.010194.001103

Aluja, M., Celedonio-Hurtado, H., Liedo, P., Cabrera, M., Castillo, F., Guillén, J., \& Rios, E. (1996). Seasonal population fluctuations and ecological implications for management Anastrepha fruit flies (Diptera: Tephritidae) in commercial mango orchards in Southern Mexico. Journal of Economic Entomolgy, 89(3), 654-667. https://doi.org/10.1093/jee/89.3.654

Alves, V. E. S. (2010). Dinâmica populacional de moscas-das-frutas (Diptera: Tephritidae) antes e após a liberação de Diachasmimorpha longicaudata (Hymenoptera: Braconidae) em área de intersecção de pomar cítrico e mata secundária (p. 90, Tese de Doutorado, Universidade Estadual Paulista "Júlio Mesquita Filho", Jaboticabal, Brazil).

Araújo, E. L. (2002). Dípteros frugívoros (Tephritidae e Lonchaeidae) na região de Mossoró/Assu, estado do Rio Grande do Norte (p. 112, Tese de Doutorado, Escola Superior de Agricultura "Luiz de Queiroz", Universidade de São Paulo, Piracicaba, Brazil).

Araújo, E. L., \& Zucchi, R. A. (2003). Moscas-das-frutas (Diptera: Tephritidae) em goiaba (Psidium guajava), em Mossoró, RN. Arquivos do Instituto Biológico, 70(1), 73-77.

Bressan, S., \& Teles, M. C. (1991). Lista de hospedeiros e índices de infestação de algumas espécies do gênero Anastrepha Schiner, 1868 (Diptera: Tephritidae) na região de Ribeirão Preto-SP. Anais da Sociedade Entomológica do Brasil, 20(1), 5-15. https://bdpi.usp.br/item/000832821

Canal, N. A., Alvarenga, C. D., \& Zucchi, R. A. (1998). Níveis de infestação de goiaba por Anastrepha zenildae Zucchi, 1979 (Dip., Tephritidae), em pomares comerciais do Norte de Minas Gerais. Anais da Sociedade Entomológica do Brasil, 27(4), 657-661. https://doi.org/10.1590/S0301-80591998000400021 
Canesin, A., \& Uchoa-Fernandes, M. A. (2007). Faunistic study and populational fluctuation of fruit flies (Diptera, Tephritidae) in a fragment of semideciduous forest in Dourados, Mato Grosso do Sul, Brazil. Revista Brasileira de Zoologia, 24(1), 185-190. https://doi.org/10.1590/S0101-81752007000100023

Fofonka, L. (2006). Espaço agrícola, ambiente e agroecologia: Incidência de moscas-das-frutas (Diptera: Tephritidae) nos pomares de laranja do município de Caraá, RS (p. 149, Dissertação de Mestrado, Universidade Federal do Rio Grande do Sul, Caraá, Brazil).

Garcia, F. R. M., \& Corseuil, E. (1998). Análise faunística de moscas-das-frutas (Diptera, Tephritidae) em pomares de pessegueiro em Porto Alegre, Rio Grande do Sul. Revista Brasileira de Zoologia, 15(4), 1111-1117. https://doi.org/10.1590/S0101-81751998000400028

Garcia, F. R. M., Campos, J. V., \& Corseuil, E. (2003). Análise faunística de espécies de moscas-das-frutas (Diptera: Tephritidae) na região Oeste de Santa Catarina. Neotropical Entomology, 32(3), 421-426. https://doi.org/10.1590/S1519-566X2003000300006

Köppen, W., \& Geiger, R. (1936). Handbuch der klimatologie (pp. 1-44). Berlin. Available at: https://www.climond.org/Public/Data/Publications/Koeppen_1936_GeogSysKlim.pdf. Accessed on: 15 Jan. 2016.

Kovaleski, A. (1997). Processos adaptativos na colonização da maçã (Malus domestica L.) por Anastrepha fraterculus (Wied.) (Diptera: Tephritidae) na região de Vacaria, RS (p. 122, Tese de Doutorado, Universidade de São Paulo, São Paulo, Brazil).

Kovaleski, A., Sugayama, R.L., Uramoto, K., \& Malavasi, A. (2000). Rio Grande do Sul. In A. Malavasi, \& A. R. Zucchi (Eds.), Moscas-das-frutas de importância no Brasil: Conhecimento básico e aplicado (pp. 285-290). Ribeirão Preto: Holos.

Malavasi, A. (2000). Áreas-livres ou de baixa prevalência. In A. Malavasi, \& R. A. Zucchi (Eds.), Moscas-das-frutas de importância econômica no Brasil: Conhecimento básico e aplicado (pp. 277-283). Ribeirão Preto: Holos.

Malavasi, A., \& Morgante, J. S. (1980). Biologia de moscas-das-frutas (Diptera: Tephritidae): II - índices de infestação em diferentes hospedeiros e localidades. Revista Brasileira de Biologia, 40(1), 17-24.

Malavasi, A., Zucchi, R. A., \& Sugayama, R. L. (2000). Biogeografia. In A. Malavasi, \& R. A. Zucchi (Eds.), Moscas-das-frutas de importância econômica no Brasil: Conhecimento básico e aplicado (pp. 93-98). Ribeirão Preto: Holos.

Nascimento, A. S., Carvalho, R. S., Malavasi, A. (2000). Monitoramento populacional. In A. Malavasi, \& R. A. Zucchi (Eds.), Moscas-das-frutas de importância no Brasil: Conhecimento básico e aplicado (pp. 109-112). Ribeirão Preto: Holos.

Nascimento, A. S., Zucchi, R. A., \& Silveira Neto, S. (1983). Dinâmica populacional das moscas-das-frutas no recôncavo baiano: III - Análise faunística. Pesquisa Agropecuária Brasileira, 18(4), 319-328.

Paranhos, B. A. J., Haji, F. N. P., Miranda, I. G., Barbosa, F. R., \& Souza, A. M. (2005). Monitoramento de moscas-das-frutas no submédio do vale do São Francisco. In E. A. Menezes, \& F. R. Barbosa (Eds.), Pragas da mangueira: Monitoramento, nível de ação e controle (pp. 85-96). Petrolina: Embrapa Semiárido.

Raga, A. (2005). Incidência, monitoramento e controle de moscas-das-frutas na citricultura paulista. Laranja, 26(2), 307-322.

Raga, A., Souza Filho, M. F., Sato, M. E., \& Cerávolo, L. C. (1996). Dinâmica populacional de adultos de moscas-das-frutas (Diptera: Tephritidae) em pomar de citros de Presidente Prudente, SP. Arquivos do Instituto Biológico, 63(2), 23-38.

Rampazzo, E. F. (1994). Dinâmica populacional de moscas-das-frutas do gênero Anastrepha (Wiedemann) (Diptera: Tephritidae), seus parasitoides e predadores coletados em pomares de goiaba (Pisidium guajava L.) nos municípios de Jaboticabal e Monte Alto-SP (p. 133, Dissertação de Mestrado, Universidade Estadual Paulista "Júlio Mesquita Filho", Jaboticabal, Brazil).

Salles, L. A. B. (1995). Bioecologia e controle da mosca-das-frutas sul-americana. Pelotas, RS: Embrapa-CPACT.

Silva, N. M. O. (2007). Dinâmica populacional de moscas-das-frutas (Diptera: Tephritidae) e ocorrência de parasitoides em um pomar de cajá (Spondias mombim L.) em Una, Bahia (p. 91, Dissertação de Mestrado, Universidade Estadual de Santa Cruz, Ilhéus, Brazil). 
Silveira Neto, S., Nakano, O., Barbin, D., \& Villa Nova, N. A. (1976). Manual de ecologia dos insetos. Piracicaba: Ceres.

Sugayama, R. L., \& Malavasi, A. (2000). Ecologia comportamental. In A. Malavasi, \& R. A. Zucchi (Eds.), Moscas-das-frutas de importância econômica no Brasil: Conhecimento básico e aplicado (pp. 103-108). Ribeirão Preto: Holos.

Uramoto, K. (2002). Biodiversidade de moscas-das-frutas do gênero Anastrepha (Diptera: Tephritidae) no campus Luiz de Queiroz, Piracicaba, São Paulo (p. 85, Dissertação de Mestrado, Escola Superior de Agricultura "Luiz de Queiroz", Universidade de São Paulo, Piracicaba, Brazil).

Uramoto, K., Walder, J. M. M., \& Zucchi, R. A. (2004). Biodiversidade de moscas-das-frutas do gênero Anastrepha (Diptera, Tephritidae) no campus da ESALQ-USP, Piracicaba, São Paulo. Revista Brasileira de Entomologia, 48(3), 409-414. https://doi.org/10.1590/S0085-56262004000300018

Uramoto, K., Walder, J. M. M., \& Zucchi, R. A. (2005). Análise quantitativa e distribuição de populações de espécies de Anastrepha (Diptera: Tephritidae) no Campus Luiz de Queiroz, Piracicaba, SP. Neotropical Entomology, 34(1), 33-39. https://doi.org/10.1590/S1519-566X2005000100005

Veloso, V. R. S. (1997). Dinâmica populacional de Anastrepha spp. e Ceratitis capitata (Wied., 1824) (Diptera, Tephritidae) nos cerrados de Goiás (p.115, Tese de Doutorado, Universidade Federal de Goiás, Goiânia, Brazil).

Yuval, B., \& Hendrichs, J. (2001). Behavior of flies in the genus Ceratitis (Dacinae: Ceratitidini). In M. Aluja, \& A. L. Norrbom (Eds.), Fruit flies (Tephritidae): Phylogeny and evolution of behavior (pp. 429-457). Boca Raton: CRC Press. https://doi.org/10.1201/9781420074468.ch17

Zucchi, R. A. (2000). Taxonomia. In A. Malavasi, \& R. A. Zucchi (Eds.), Moscas-das-frutas de importância econômica no Brasil: Conhecimento básico e aplicado (pp. 13-24). Ribeirão Preto: Holos.

\section{Copyrights}

Copyright for this article is retained by the author(s), with first publication rights granted to the journal.

This is an open-access article distributed under the terms and conditions of the Creative Commons Attribution license (http://creativecommons.org/licenses/by/4.0/). 